\title{
Leadership Development through Project Based Learning
}

\author{
Karen Cain and Sandra Cocco \\ Conestoga College Institute of Technology and Advanced Learning \\ Kcain@conestogac.on.ca
}

\begin{abstract}
The traditional hierarchical model of leadership is outdated and in its place are flatter industrial models where leadership is shared amongst the various individuals in a team. The modern team based project is an essential method used to create successful endeavors. Engineers must be trained to lead and participate in multidisciplinary teams. The learning process of becoming an effective leader and a valued team member must begin through the introduction of leadership skills during undergraduate engineering education. Project Based Learning (PBL) is an example where such training can have a profound influence on the learner, enabling growth of future leaders.

Project Based Learning has long been touted as an excellent method of active learning which greatly facilitates application and retention of theory. Its use to improve 'soft skills' such as communication, individual growth, life-long learning and team-work is also evident. Difficulties with PBL are more often institutionally-based involving implementation on a large scale and faculty enthusiasm and time commitments. This paper expands on the use of PBL as a method to develop student leaders focusing on individual student experiences within team environments. It introduces various PBL approaches and their implementation within an existing engineering educational framework.
\end{abstract}

Keywords: Project-Based Learning, Leadership Activities, PBL Models, Engineering Education, Active Learning.

\section{INTRODUCTION}

In academic circles, it is understood that teaching and learning can take place in many ways: lectures, tutorials, laboratories, readings, assignments etc. Another technique is through the application of theory to projects, where theory can be taught and applied concurrently. This is widely known as Project Based Learning (PBL), an active form of learning suitable to a variety of learning styles. PBL has been historically recognized as promoting the demonstration and retention of knowledge. In addition, it offers improved team and leadership skills development.
There are many different leadership models that have emerged over time; some have endured and some have disappeared. Leadership models are often broken down into hierarchical and flat management models. Modern industry is moving towards flatter, less hierarchical structures[1] where leaders are situational and collaboration is dynamic and non-coercive. This relational model allows leadership to rotate and power be shared. Titles such as managers and team leads are not necessarily required. Many researchers have studied this model [2-9]. Even the Canadian military is attempting to modify its leadership structure to permit rotational and shared leadership roles encouraging more immediate decision making in the field where direct action may be required[10].

Project Based Learning is an ideal format for showcasing this type of non-hierarchical leadership. Leadership not only involves the training of leaders, but also that of followers or team members. Lambert indicated that all students should be encouraged to be leaders at some point during their schooling and that leading is a key part of the learning process [11]. If engineers need leadership skills after graduation then it is up to undergraduate educators to equip them with this expertise[12]. Learning to lead can be greatly facilitated by active learning [13] where students 'learn by doing' such as in Project Based Learning (PBL).

PBL is well known for its ability to promote retention of application of theory [14]. In addition, the integration of concepts across courses permits large real-world projects. This integration and ability to see the project as a whole allows students to be 'big picture' learners and gives exposure to many 'soft skills' including team work and effective leadership [12,14-17].

Several qualities are shown to be improved through active learning or PBL. These include improved [13,15, 18-20]:

1. Sense of social, civic, political, ethical and diversity awareness

2. Willingness to take risks

3. Communication skills

4. Teamwork skills

5. Ability to set goals and make decisions

6. Self-esteem and self-understanding 
7. Problem solving and critical thinking skills

8. Conflict resolution

9. Likelihood of sharing power

\section{LEADERSHIP OUTCOMES AND PROJECT BASED LEARNING}

\subsection{A Hybrid Application of PBL and Leadership Activities}

Several models of PBL exist; however, the example examined for this paper uses yearly projects that are integrated into an otherwise course-based curriculum. This is known as a hybrid PBL model in which projects integrate the learning outcomes of as-many-as-possible concurrently taught courses. In order to facilitate the development of non-engineering skill development, nontraditional courses are also integrated into the curriculum. Leadership is taught within the program in a couple of ways. First, the students are explicitly taught leadership skills though courses such as Group Dynamics, Project Management and Topics in Management. Courses are delivered in a just-in-time method in order to complement the pedagogy of the projects within the PBL curriculum. Second, the students are able to freely explore and practice leadership within the projects themselves. Students are evaluated for some skill development, although for reasons that will be explored later, this can be a difficult undertaking.

2.1.1 A Foundation Course in Group Dynamics. At the beginning of the undergraduate program, it is important for students to learn interpersonal skills and how groups work together to achieve a larger goal [21]. The course is strategically located as a three-credit-hour, three-weekcourse at the end of August each year so that students are able to explore group work and the theory behind group work before tackling the first year engineering project. It has been developed as a Problem Based Course where the students learn about the theory of working in teams by rotating through various team positions, teaching and evaluating their performance while working through sections of the textbook. The textbook used in the course is "Small Group and Team Communication" by Thomas E. Harris and John C. Sherblom, published by Pearson. The following is a quote from a student with regards to their experience taking this course:

"I remember looking back at what I learned in the Group Dynamics course. It's a course we take in the summer before we start classes. It helped me understand leadership styles. Through the teaching in this course, we developed a plan that helped us address issues such as learning how to help people who could not admit they needed help" - Student

Throughout the course, each team of four students rotates through situations or lessons including, executive, review, teaching, evaluation and energizer. Then, inside each team, the students are given specific job titles and responsibilities to support the team objectives for that lesson. Team jobs include: team leader, team recorder, team reporter and team analyst. The jobs are rotated so that each student is exposed to all of the different responsibilities.

Using the role of team leader as an example, the following are the specific responsibilities of that job:

1. Call and chair team meetings, developing agendas in consultation with team members.

2. Ensure the individual team members carry out their responsibilities and ensure that the team, as a whole, fulfills its responsibilities.

3. Communicate with other team leaders as necessary.

4. Submit a memo on team progress to the consultant (the Professor) at the end of the team meeting.

5. Ensure the team folder is up to date, orderly, and handed in at the end of all classes.

6. Review all team reports and ensure they are properly completed.

7. During the evaluation session, record the feedback the team receives.

8. At the end of the term, collect all reports and hand them in, along with submitting of a "Leader Report".

2.1.2 Project Management. A course containing the principal concepts of project management is a key element to a successful Project Based Learning curriculum. Its placement within students' undergraduate studies may depend on the timing of projects and amount of project planning required. For example, a first year project where students are following an explicit set of design requirements and very detailed task lists may not require students to apply many project management skills. However, if the project requirements given are only general guidelines and major milestones then students need to be taught how to actively determine objectives and tasks and to correctly appropriate time and resources to meet the project deadlines.

2.1.3 Yearly PBL Projects. In this particular approach there are four projects, one in each of the four years of the undergraduate program. Each of the projects integrates as much of the material as possible from on-going courses. Figure 1 shows an example of how the courses and projects are integrated with the project as a central focus 
and intersection point. The hybrid model of Project Based Learning depends on courses that exist and orbit around the PBL project rather than depending on all outcomes being delivered through the project itself.

In year 1 of the program, the project is an introduction that allows students to apply basic engineering theory and to try out some of the roles involved in leadership and teamwork. In the project, groups of five students complete the re-engineering, manufacture and control of a 'robotic crane'. Project assignments and tasks are assigned by both the Project Coordinator and also by course Faculty. Evaluation of the students involved in the project is also shared. Here, team leaders for the individual tasks are rotated among the group members. Weekly status reports and review meetings are a regular part of the project class.

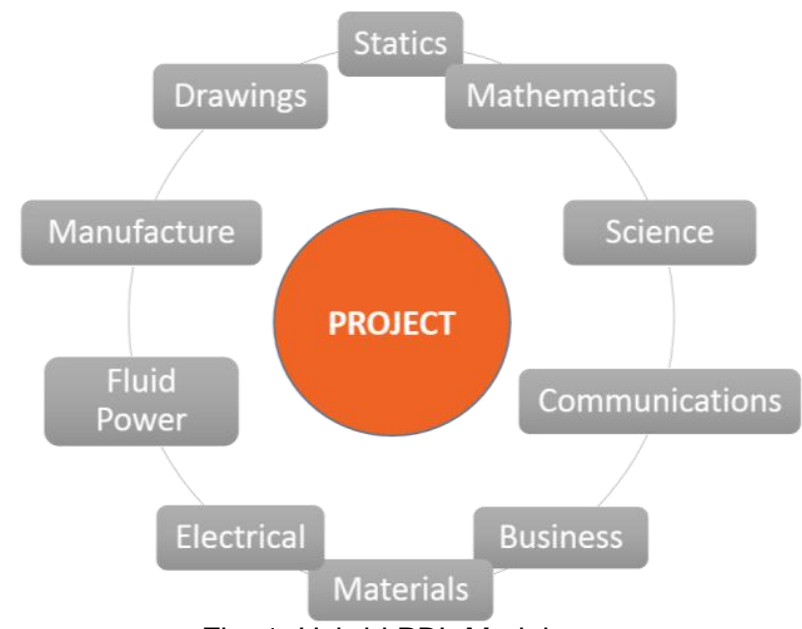

Fig. 1. Hybrid PBL Model.

The PBL project within the second year of the undergraduate program has students using material from their freshman year as well as concurrently taught course subjects. Here, groups of three students design and build a 'pick-and-place' robot to interface with a small forming press. Project deliverables and milestones are specified by project and course faculty, but students are able to exhibit more creativity in their project design and have much more leeway in their management/leadership structure.

By the time that students arrive in their third year, they are ready to participate in a large group project (12-20 students). Again, the PBL project is integrated with the curriculum. Students design and build a 'real-world' prototype of a machine for an actual industry partner. The class is split into smaller groups in order to facilitate the design of subcomponents. The Project Coordinator acts as coach and mentor. The students are frequently asked to interface with customers and suppliers alike. Leadership tasks are not formally assigned or rotated, but students generally informally share and swap the leadership role depending on their strengths with regards to the tasks at hand.
In the final year, the students have a Capstone PBL project which is also integrated with Year 4 curriculum. In groups of 12 to 20, students design a product, verify its economic feasibility, and develop a simulation of the plant to manufacture the product. Similar to the project in the previous year, students are divided into sub-groups with a focus on the subcomponents of large assemblies and structures of the design. Leadership is informal and manifests itself similar to that in Year 3.

2.1.4 Final Year Management Course. In the final year of the program it also makes sense to add to the leadership and management skills of engineering students in a justin-time fashion. The final year capstone project is intense and also the students are actively planning their future jobs which may include management activities. This course contains many different topics, but alternatively the curriculum may be partitioned into courses such as Professional Practice or the capstone project itself. Topics include: career planning, hiring, workplace laws, manager guidelines, negotiation skills and even business strategies. This course is a summary of the skills that students have acquired, fills any gaps that may be missing and enriches their leadership skills for the years ahead.

\section{MEASUREMENT OF LEADERSHIP IN A PROJECT BASED LEARNING ENVIRONMENT}

\subsection{A Qualitative Study of Leadership in PBL}

This section outlines a qualitative study in which a set of one-on-one student interviews was completed to determine the students' views on leadership and how PBL program described previously has affected their abilities to lead, and follow, within a team. The students were a small group of third year students totaling 7 individuals or approximately $25 \%$ of the cohort [16].

When students were asked about leadership within the context of their projects, the results had four themes which indicate an insightful understanding of the roles and activities of leadership [16]:

- Participation based on personal strengths

- Non-positional leaders / leadership without authority

- Shifting roles and inclusive participation

- Collaboration

The free flowing nature of the interviews permitted students to talk generally about their project work and how they worked in a team. All of the leadership activities listed in Section 1 were mentioned by at least one student and several activities such as diversity awareness,

CEEA13; Paper 126 
communication skills, decision-making and sharing of power were discussed by most students. As expected, team work skills were mentioned by all students (see Table 1).

Table 1. Perceived Impacts to Leadership Skills within a PBL Environment

\begin{tabular}{|l|l|l|l|l|l|l|l|}
\hline & \multicolumn{7}{|c|}{ Student } \\
\hline Leadership Activities & 1 & 2 & 3 & 4 & 5 & 6 & 7 \\
\hline $\begin{array}{l}\text { Increased sense of social, } \\
\text { civic, political, ethical \& } \\
\text { diversity awareness }\end{array}$ & $\mathrm{X}$ & $\mathrm{X}$ & $\mathrm{X}$ & & $\mathrm{X}$ & $\mathrm{X}$ & \\
\hline $\begin{array}{l}\text { Increased willingness to } \\
\text { take risks }\end{array}$ & & & & $\mathrm{X}$ & $\mathrm{X}$ & & $\mathrm{X}$ \\
\hline $\begin{array}{l}\text { Improved } \\
\text { communication }\end{array}$ & $\mathrm{X}$ & $\mathrm{X}$ & $\mathrm{X}$ & $\mathrm{X}$ & $\mathrm{X}$ & $\mathrm{X}$ & \\
\hline $\begin{array}{l}\text { Improved teamwork } \\
\text { skills (building } \\
\text { consensus \& trust, } \\
\text { working collaboratively) }\end{array}$ & $\mathrm{X}$ & $\mathrm{X}$ & $\mathrm{X}$ & $\mathrm{X}$ & $\mathrm{X}$ & $\mathrm{X}$ & $\mathrm{X}$ \\
\hline $\begin{array}{l}\text { Increased ability to set } \\
\text { goals \& make decisions }\end{array}$ & $\mathrm{X}$ & $\mathrm{X}$ & $\mathrm{X}$ & & & $\mathrm{X}$ & $\mathrm{X}$ \\
\hline $\begin{array}{l}\text { Improved self-esteem \& } \\
\text { self-understanding }\end{array}$ & $\mathrm{X}$ & $\mathrm{X}$ & & & $\mathrm{X}$ & $\mathrm{X}$ & $\mathrm{X}$ \\
\hline $\begin{array}{l}\text { Improved problem } \\
\text { solving abilities \& } \\
\text { critical thinking skills }\end{array}$ & $\mathrm{X}$ & $\mathrm{X}$ & & & $\mathrm{X}$ & & \\
\hline $\begin{array}{l}\text { Improved conflict } \\
\text { resolution }\end{array}$ & $\mathrm{X}$ & & & & & $\mathrm{X}$ \\
\hline $\begin{array}{l}\text { Improved likelihood of } \\
\text { sharing power }\end{array}$ & $\mathrm{X}$ & & $\mathrm{X}$ & $\mathrm{X}$ & $\mathrm{X}$ & & $\mathrm{X}$ \\
\hline $\begin{array}{l}\text { Giving constructive } \\
\text { feedback }\end{array}$ & & & $\mathrm{X}$ & $\mathrm{X}$ & & \\
\hline
\end{tabular}

Note that the example discussed was a qualitative study and does not measure leadership outcomes of students as they progress through the undergraduate PBL program. The ability to evaluate all aspects of leadership is challenging and stems from the lack of clear definition of leadership [16] and the difficulty of measuring skills such as, for example, an ability to adapt quickly to changing conditions or make decisions where ambiguity exists.

A dialogue involving options to improve grading of leadership skills and feedback given to students is needed. Possibilities might include:

1. Self-evaluation and reflection of the student

2. Peer evaluation within the team

3. Professor evaluation based on observation

4. Professor evaluation based on case study response by all students

5. A combination of the above

But first, a list of leadership activities need to be prescribed and rubrics constructed for evaluation.

\subsection{The Implementation of PBL within an Existing Educational Framework}

PBL is not without its critiques. Similar to all styles of teaching, it can be done well or poorly. Even when done well with enthusiastic students and faculty and support from Deans and Chairs, it can be both time consuming and expensive and it is often difficult to scale up for use in larger class cohorts.

The example studied in this paper was for a class of 30 . Scaling up PBL to enable delivery to class sizes of 100 or 200 students requires some foresight. In many ways it is not significantly different than the subdivision of students for laboratory and tutorial sessions. However, faculty need to be more directly involved and take on a larger role with facilitators or teaching assistants taking on a more minor role in project sessions.

Students may find that the additional workload associated with projects adds to the existing heavy workload of engineering courses. Experience shows however, that few students would trade this experience. Visiting exchange students from European engineering schools who had very little prior experience with this type of learning have indicated that "it was a lot of work, but also a lot of fun".

Faculty commitment to Project Based Learning is another key factor to PBL success. This is true of both the Project Coordinator who is actively managing/facilitating the project work and also the faculty teaching the supporting curriculum courses running concurrently. A breakdown in communication involving the faculty team is as detrimental, if not more so, as a lack of communication within the student teams. Regular weekly communication is a must. In addition, the cost of PBL learning is higher than traditional lectures due to the increased faculty time required. This includes the mentoring and coaching within the project time and faculty group meetings. PBL can be facilitated by student homerooms (where students may work on projects afterhours) and locating faculty offices within close proximity to each other.

Solid and continuous faculty commitment is often difficult to acquire due to the decreased autonomy, the lack of faculty industrial practical experience and time commitments required. Courses are often viewed as 'islands' unto themselves with faculty able to create and modify outcomes according to their own agendas/biases and research interests. This segregation of courses and subject areas needs to be changed to allow full integration within a PBL curriculum. Increasingly, faculty have little or no industrial experience and this can lead to difficulties with their ability to step beyond their very specialized area of research expertise[22]. Also, additional time 
commitments include the necessary organizational meetings with other program faculty and meetings with individual project groups. None of the problems listed above are insurmountable, but need to be solved before PBL can be successfully implemented.

Some engineering schools become frustrated by the idea of PBL since it is often believed that there is a need to throw away all existing curriculum in order to implement PBL curriculum instead; a daunting procedure indeed. The following figure outlines PBL as a continuum with no projects on the left hand side and a fully integrated PBL curriculum where little or no 'courses' exist on the right hand side (see Fig.2). The idea here is that PBL can be slowly integrated.

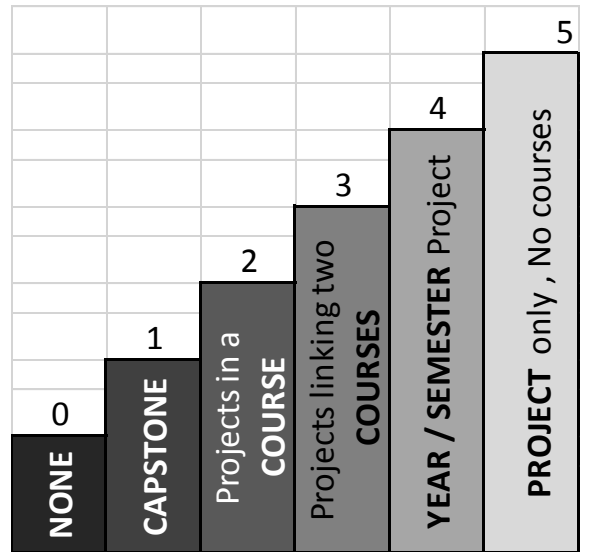

Fig. 2. PBL as a Continuum of Steps.

Often in engineering programs, there is a capstone project, a final evaluation of the attributes required of a graduate. The main drawback is that this method doesn't allow the students to practice their skills and for faculty to truly evaluate students' abilities as they progress through the different years of their academic program. Alternately, there are often projects within an individual course allowing students to demonstrate their creativity and problem solving skills albeit within a narrow subject area. This also is a step in the PBL continuum.

For the slow integration of PBL, the next step would be to add projects that combine the learning from two or more courses. This could be evaluated within the few courses that participate or alternately, the courses could be combined to create a project course in which the participating subject areas are taught. Unlike the capstone project, here, new information is taught, processed by the students and evaluated by faculty on a continuous basis. In Step 4, the year/semester project teaches new information and also evaluates previous learning. Finally, moving towards full integration of course material with the elimination of the courses themselves, is what constitutes a fully Project Based program where learning occurs in subject area courses and within the project.
These steps can be taken one at a time or jumped to directly using curriculum redesign. Also, it should be noted that it not necessary to end up at Step 5. The program described in the previous study is currently at Step 4 with no intention of moving beyond. The skills gained improve with each step but greatest benefit comes from having a project which integrates learning across different courses.

\section{CONCLUSIONS}

Project Based Learning has historically been shown to be a useful tool in the application and practice of engineering theory, as well as integration of engineering concepts. It is also an enabler to the development and growth of leadership competencies such as the ability to work within diverse teams, set goals and make decisions, communicate effectively and many others. PBL can be slowly and effectively implemented though step-wise improvements to engineering curriculum to facilitate these outcomes.

\section{Acknowledgements}

I would like to acknowledge my department and colleagues at Conestoga College for their support and contributions.

\section{References}

[1] Lloyd Dobyns and Claire Crawford-Mason, Quality or else: The revolution in world business. Boston: Houghton Mifflin, 1991. \{ISSN: 8755-1977\}

[2] Wilfred Drath, The deep blue sea: Rethinking the source of leadership. San Fransico: Jossey Bass, 2001 \{ISBN: 9780787-94932-7\}

[3] Alexander W. Astin and Helen S Astin, Leadership Reconsidered: Engaging higher education in social change. Los Angeles: W.K. Kellogg Foundation, 2000.

[4] Richard Barker, "How can we train leaders if we do not know what leadership is?" Human Relations, vol. 50, no. 4, pp. 343-362, 1997.

[5] Ronald Heifetz, Leadership without easy answers. Cambridge, MA: Belknap Press of Harvard University Press, 1994. \{ISBN:978-0674-51858-2\}

[6] Susan R. Komives, Nance Lucas and Timothy R McMahon, Exploring leadership: For college students who want to make a difference. San Francisco: Jossey Bass, 1984. \{ISBN:978-118-39947-7\}

[7] Charles L. Outcalt, Shannon K. Faris, Kathleen N. McMahon, Philip M. Tahtakran and Christopher B. Noll, “A 
leadership approach to the new millennium: A case study for UCLA's Bruin Leaders Project," NASPA Journal, vol.38, no. 2 , pp. 178-187, 2001.

[8] Joseph C. Rost, "Leadership development in the new millennium," The Journal of Leadership Studies, vol. 1, no. 1, pp. 91-110, 1993.

[9] Jeffrey Yip, Joseph A. Raelin, "Threshold concepts and modalities for teaching and leadership practice," Management Learning, vol. 43, no. 3, pp. 333-354, 2011.

[10] Alan Okros, "The command team: A valuable evolution of doctrinal danger?" Canadian Military Journal, vol. 13, no. 1, pp. 15-22, 2012.

[11] Linda Lambert, "Leadership capacity for lasting school improvement," Alexandria, VA: Association for Supervision and Curriculum Development, 2003. . \{ISBN:978-087110778-4\}

[12] Sanjeev Kumar, "Industry preparation in a capstone design course," in Proc. International Conference on Engineering Education, International Network for Engineering Education and Research, (Taiwan, August 13-18, 2000).

[13] Charles L. Outcalt, Shannon K. Faris and Kathleen N. McMahon, Developing non-hierarchical leadership on campus: Case studies \& best practices in higher education. Westport, CT: Greenwood Publishing, 2000. . \{ISBN:9780313-31178-9\}

[14] Debbie Lam, "Problem-based learning: An integration of theory and field," Journal of Social Work Education, vol. 40, no. 3, pp. 371-388, 2004.

[15] Sanjeev Kumar and J. Kent Hsaio, "Engineers Learn "Soft Skills the Hard Way": Planting a seed of leadership in engineering classes," Leadership and Management in Engineering, pp. 18-23, January 2007

[16] Sandra Cocco, Student Leadership Development: The Contribution of project-based learning. Diss. Masters thesis, Royal Roads University (Canada), 2006.

[17] Russell C. Walters and Todd Sirotiak, "Assessing the effect of project based learning on leadership abilities and communication skills," in Proc. $47^{\text {th }}$ ASC Annual International Conference, Associated Schools of Construction, (Omaha, NE, April 6-9, 2011).

[18] Kathleen Zimmerman-Oster and John Buckhardt, "Leadership in the making: A comprehensive examination of the impact of leadership development programs on students in U.S. colleges and universities," Journal of Leadership and Organizational Studies, vol. 6, no. 3-4, pp. 50-66, 1999.

[19] Tara J. Fenwick, "Problem-based learning, group process and the mid-career professional: Implications for graduate education," Higher Education and Development, vol. 21, no. 1, pp. 5-21, 2002.

[20] Douglas H. Berg, Prospective leadership development in colleges and universities in Canada: Perspectives of leaders, educators and students. Ph.D. Diss. , University of Saskatchewan, 2003.

[21] Joe Raelin, "Does action learning promote collaborative leadership," Academy of Management, vol. 5, no. 2, pp. 152-168, 2006.

[22] Ruth Graham, "UK approaches to engineering projectbased learning," White Paper sponsored by the Bernard M. Gordon MIT Engineering Leadership Program, Boston MA 2010 . 